\section{Prof. F. P. Purvis}

THE announcement of the death at Seaford, on February 20, of Prof. Frank Prior Purvis will be read with regret by all those interested in the progress of naval architecture, for he was the last surviving assistant of William Froude at the Admiralty Experimental Tank at Torquay.

Prof. Purvis was nearly ninety years of age, having been born on April 18, 1850. The son of Dr. Prior Purvis, he was educated at Blackheath School, and during 1867-70 was trained as a shipwright under the Admiralty at Deptford and Chatham Dockyards, and in the old Royal School of Naval Architecture and Marine Engineering at South Kensington. While passing through his training, he gained a Whitworth scholarship, being one of the first to do so. After a short time spent at the yard of Robert Napier on the Clyde, and on the staff of Sir Edward Reed, who in 1870 had resigned the post of chief constructor at the Admiralty, Purvis joined Froude at Torquay in 1871, and remained with him for six years. From Torquay he went to Govan, serving under Sir William Pearce, but in 1879 he became head of the scientific staff of Messrs. William Denny and Brothers, Dumbarton.

Froude had no greater admirer than William Denny III (1847-87), through whose initiative the firm constructed an experimental tank similar to, but slightly longer than, the Torquay Tank. This was the first tank to be erected by a shipbuilder, and the facade of it bears an inscription saying that it was erected in memory of Froude, "the Greatest of Experimenters and Investigators in Hydrodynamics". The first experiments were made in the tank in February 1883, and later tests proved of great value in the development of the designs for the cross-Channel vessels for which the firm is well known.

Leaving Dumbarton in 1889 , for the next ten years Purvis was a partner in the firm of Blackwood and Gordon, Port Glasgow, and two years after severing his connexion with them he entered upon his long career of teaching in Japan.

The interesting story of the rise of engineering education in Japan dates back to the 'seventies of last century, when Dyer, Marshall, Alexander, Divers, Perry, Ewing, Ayrton, Milne and others went out from Great Britain to teach in the old College of Engineering (Kobu Daigakko), now a part of the Tokyo Imperial University, and when British naval engineers were lent to the Japanese Admiralty. Instruction in naval architecture was originally started in the College by the late Prof. S. Miyoshi, who had learnt shipbuilding under Robert Napier, but in 1899 the authorities invited Prof. P. A. Hillhouse to occupy the chair of naval architecture in the University, and it was his post to which Purvis succeeded in 1901.

Purvis held the chair for nineteen years, during which time, from a place of insignificance, Japan rose to be one of the chief shipbuilding countries in the world. From an output of about 3,000 tons in 1900 , the tonnage launched rose year by year until in 1919 the output exceeded 600,000 tons. Early in the century, too, the Japanese Government built an experimental tank, $494 \mathrm{ft}$. long, at Nagasaki.

For his long services in Japan Purvis was decorated with the orders of the Rising Sun and Sacred Treasure. He was a member of the Institution of Civil Engineers, the Institution of Naval Architects and the Institution of Engineers and Shipbuilders of Scotland, to which he contributed a few papers.

\section{The Rev. Hilderic Friend}

The Rev. Hulderic Friend died in his eightyeighth year at his home in Solihull, Birmingham, after a long illness. He was born at High Wigsell in Kent in 1852, but spent his early years in the vicinity of Hastings and always regarded himself as a Sussex man. In 1874 he entered the Wesleyan College at Richmond to train for the ministry, and two years later he sailed as a missionary to China. Ill-health compelled him to return home in 1880 and, with a view to his recuperation, he was given a series of country circuits for his pastoral care. His first was at Newton Abbott in Devonshire, where he spent much time in the open air and began to study field botany systematically. Here he wrote "A Glossary of Devonshire Plant Names". This was succeeded in 1884 by "Flowers and Flower Lore" and by "The Ministry of Flowers" in 1885.

After travelling all over the country in his ministerial capacity, Mr. Friend retired in 1914. For many years he had interested himself in worms, and he now devoted his leisure to their more thorough study.

As the result of his labours science was enriched with the knowledge of many new species, and contributions from his pen have frequently appeared in the columns of NATURE. He was a voluminous writer, and was the author of more than a dozen books and of several thousand articles. In 1937 he successfully recovered from a serious operation, but a few weeks later his wife passed away. He never recovered from the blow. He died on February 7, leaving a son, Dr. J. A. Newton Friend, who is head of the Chemistry Department, Technical College, Birmingham, and a daughter.

\section{WE regret to announce the following deaths:}

Prof. W. C. Brøgger, rector of the University of Oslo and a foreign fellow of the Geological Society of London, on February 17, aged eighty-eight years.

Dr. R. T. Gunther, curator of the Oxford Museum for the History of Science, University reader in the history of science, on March 9, aged seventy years.

Prof. E. Maragliano, emeritus professor of clinical medicine in the University of Genoa, a pioneer in tuberculosis research, aged ninety-one years.

Prof. Károly Schaffer, emeritus professor of neurology and psychiatry in the University of Budapest, aged seventy-five years. 